\title{
A comparative study on thermal behavior of solid-state light trivalent lanthanide isonicotinates in dynamic dry air and nitrogen atmospheres
}

\author{
W. D. G. Nunes ${ }^{1}$ J. A. Teixeira ${ }^{1}$ A. L. C. S. do Nascimento ${ }^{1}$ F. J. Caires ${ }^{2}$. \\ E. Y. Ionashiro ${ }^{3} \cdot$ M. Ionashiro ${ }^{1}$
}

Received: 23 October 2015 / Accepted: 3 February 2016/Published online: 24 February 2016

(C) Akadémiai Kiadó, Budapest, Hungary 2016

\begin{abstract}
Characterization, thermal stability, and thermal decomposition of light trivalent lanthanide isonicotinates $\mathrm{Ln}(\mathrm{L})_{3} \cdot 2 \mathrm{H}_{2} \mathrm{O}(\mathrm{Ln}=\mathrm{La}$ to $\mathrm{Gd}$, except $\mathrm{Pm} ; \mathrm{L}=$ isonicotinate) were investigated employing simultaneous thermogravimetry and differential scanning calorimetry (TGDSC), DSC, infrared spectroscopy (FTIR), evolved gas analysis by TG-DSC coupled to FTIR, elemental analysis, and complexometry. The dehydration of these compounds occurs in a single step, and the thermal decomposition of the anhydrous compounds occurs in one or two (air) and two or three steps $\left(\mathrm{N}_{2}\right)$. The final residues of thermal decomposition were $\mathrm{CeO}_{2}, \mathrm{Pr}_{6} \mathrm{O}_{11}$, and $\mathrm{Ln}_{2} \mathrm{O}_{3}(\mathrm{Ln}=\mathrm{La}$, $\mathrm{Nd}$ to $\mathrm{Gd}$ ) in air atmosphere, while in $\mathrm{N}_{2}$ atmosphere the mass loss is still being observed up to $1000{ }^{\circ} \mathrm{C}$. The results also provided information concerning the gaseous products evolved during the thermal decomposition in dynamic dry air and nitrogen atmospheres.
\end{abstract}

Keywords Lanthanide isonicotinates - Thermal behavior · Evolved gas analysis

Electronic supplementary material The online version of this article (doi:10.1007/s10973-016-5339-4) contains supplementary material, which is available to authorized users.

M. Ionashiro

massaoi@yahoo.com.br

1 Instituto de Química, Universidade Estadual Paulista, CP 355, Araraquara, SP 14801-970, Brazil

2 Faculdade de Ciências, Universidade Estadual Paulista, Bauru, SP 17033-260, Brazil

3 Instituto de Química, Universidade Federal de Goiás, Campus Samambaia, Goiânia, GO 74690-900, Brazil

\section{Introduction}

The interest in the coordination compounds of lanthanide metals comes from its interesting luminescent, magnetic and electronic properties. The coordination number of lanthanide ions allows designing a variety metal-ligand structures in order to achieve desired properties, based on the known chemistry of these metals. Depending on the ligand, as well as the synthetic route employed, these compounds can manifest different properties, e.g., enhanced luminescence, due to the so-called antenna effect; high porosity, due to the cross-linked three-dimensional arrangement of metal-ligand structure, which leads to interesting catalytic and adsorption properties [1].

Isonicotinic acid (4-pyridinecarboxylic acid), a nicotinic acid isomer, is a compound that contains a six-membered ring with five carbon atoms and one nitrogen (pyridine), which replaces one carbon-hydrogen unit in the benzene ring, and a carboxylic group in the position 4. Its main use is as antituberculosis drug, especially the isoniazid (isonicotinic acid hydrazide), the most effective [2]. In addition, isonicotinic acid and its derivatives are used in the production of pharmaceuticals and agrochemicals. An interesting property of isonicotinic acid is its ability to form three-dimensional polymeric structures with transition metal ions and lanthanides, binding by the nitrogen atom from the pyridine ring, and by the carboxylic group oxygens [3-5]. Some isonicotinic coordination compounds obtained by different synthetic routes and with different structures are well known [6-11]. Some of them presents biological properties, as in preventing intravenous thrombosis [neodymium(III) and samarium(III) isonicotinate]. The terbium(III) compound presents a high luminescence intensity and is a promising compound to create luminescent materials [12]. 
A literature survey reveals some studies of lanthanide isonicotinates, concerning essentially its crystalline structure and luminescence properties. In this way, the synthesis and thermal characterization of lanthanides coordination compounds with isonicotinic acid aim to contribute to this area, providing information of its thermal behavior, crystalline transitions and thermal stability (TG-DSC and DSC); gaseous decomposition products (TG-FTIR), in air and nitrogen atmosphere, until now are unreported on the literature.

\section{Experimental}

\section{Materials}

The isonicotinic acid with $99 \%$ purity was obtained from Aldrich and used as received. Lanthanide oxides $\left(\mathrm{Ln}_{2} \mathrm{O}_{3}\right.$ $\mathrm{Ln}=\mathrm{La}, \mathrm{Nd}, \mathrm{Sm}, \mathrm{Eu}, \mathrm{Gd}$ and $\left.\operatorname{Pr}_{6} \mathrm{O}_{11}\right)$ all from Aldrich with $99.9 \%$ purity were used as lanthanide(III) ions precursors, except for cerium which was used as its nitrate salt $\left[\mathrm{Ce}\left(\mathrm{NO}_{3}\right)_{3} \cdot 6 \mathrm{H}_{2} \mathrm{O}\right]$.

\section{Synthesis}

Aqueous solution of sodium isonicotinate $0.1 \mathrm{~mol} \mathrm{~L}^{-1}$ was prepared by neutralization of aqueous solution of isonicotinic acid with sodium hydroxide solution $0.1 \mathrm{~mol} \mathrm{~L}^{-1}$ until $\mathrm{pH}$ 6.5.

Lanthanide chlorides were prepared from the corresponding metal oxide (except for cerium) by treatment with concentrated hydrochloric acid, following the procedure described in [13]. Cerium(III) was used as its nitrate, and c.a. $0.1 \mathrm{~mol} \mathrm{~L}^{-1}$ aqueous solution of this ion was prepared by direct weighing of the salt.

Solid-state compounds were obtained by adding with stirring $155.0 \mathrm{~mL}$ of sodium isonicotinate solution $0.1 \mathrm{~mol} \mathrm{~L}^{-1}$ heated up to near ebullition to $50.0 \mathrm{~mL}$ of the respective metal ions solutions $0.1 \mathrm{~mol} \mathrm{~L}^{-1}$. For all the compounds, the beginning of precipitation was observed after total addition of the ligand solution. Thus, the suspensions of the respective metal isonicotinates were evaporated up to near dryness in a water bath, washed with ethanol/water (2:3) mixture until the elimination of chloride ions (qualitative test with $\mathrm{AgNO}_{3} / \mathrm{HNO}_{3}$ solution), dried at $80{ }^{\circ} \mathrm{C}$ in a forced air circulation oven during $12 \mathrm{~h}$, and kept in a desiccator over anhydrous calcium chloride.

\section{Experimental equipment and conditions}

In the solid-state, metal ions, hydration water, and isonicotinate contents were determined from TG curves. The metal ions were also determined by complexometry with standard EDTA solution after igniting the compounds to the respective oxides and their dissolution in hydrochloric acid solution [14, 15].

Carbon, nitrogen, and hydrogen contents were determined by microanalytical procedures with a $\mathrm{CHN}$ elemental analyzer from PerkinElmer, model 2400, and from TG curves.

X-ray powder patterns were obtained by using a Siemens D-5000 X-ray diffractometer employing CuKa radiation $(\lambda=1.541 \AA$ ) and setting of $40 \mathrm{kV}$ and $20 \mathrm{~mA}$.

The attenuated total reflectance infrared spectra for sodium isonicotinate and for its metal ion compound were run on a Nicolet iS 10 FTIR spectrophotometer, using ATR accessory with Ge window and DTGS detector. The FTIR spectra were recorded with 32 scans per spectrum at resolution of $4 \mathrm{~cm}^{-1}$.

Simultaneous TG-DSC curves were obtained in a TGDSC1 Mettler Toledo thermal analysis system. The purge gases were dry air and nitrogen with flow of $50 \mathrm{~mL} \mathrm{~min}{ }^{-1}$. Heating rate of $10^{\circ} \mathrm{C} \mathrm{min}{ }^{-1}$ was adopted, with samples weighing about $10.0 \mathrm{mg}$. Alumina crucibles were used for recording the TG-DSC curves.

The evolved gas analysis (EGA/TG-FTIR) experiments were performed coupling the thermogravimetric analyzer to the FTIR spectrometer Nicolet with a gas cell and DTGS $\mathrm{KBr}$ detector. The furnace and the heated gas cell $\left(250{ }^{\circ} \mathrm{C}\right)$ were coupled through a heated $\left(225^{\circ} \mathrm{C}\right) 120-\mathrm{cm}$ stainless steel transfer line with internal diameter of $3 \mathrm{~mm}$, both purged with dry air and nitrogen $\left(50 \mathrm{~mL} \mathrm{~min}^{-1}\right)$. The FTIR spectra were recorded with 16 scans per spectrum at a resolution of $4 \mathrm{~cm}^{-1}$.

The DSC curves were obtained using differential scanning calorimeter, model Q10 form TA Instruments. The purge gases were dry air and nitrogen, with flow rate of $50 \mathrm{~mL} \mathrm{~min}^{-1}$. A heating rate of $10^{\circ} \mathrm{C} \min ^{-1}$ was adopted with samples weighing about $2 \mathrm{mg}$. Aluminum crucibles with perforated covers was used for recording the DSC curves.

The DSC-photovisual images were obtained on equipment Mettler Toledo DSC-1 stare system coupled to Olympus digital camera, model SC 30. This camera incorporates a 3.3-megapixel CMOS sensor, optical subassembly mechanic Navitar $1-6232 \mathrm{D}$ with $6.5 \times$ zoom. The experimental conditions were the same used to obtain the DSC curves.

\section{Results and discussion}

The analytical and thermoanalytical (TG) data are shown in Table 1. These results permitted to establish the stoichiometry of these compounds, which are in agreement with the general formula $\mathrm{LnL}_{3} \cdot 2 \mathrm{H}_{2} \mathrm{O}$, where $\mathrm{Ln}$ represents 
light trivalent lanthanides (except promethium) and $\mathrm{L}$ is isonicotinate.

\section{XRD}

The X-ray diffraction powder patterns (Fig. 1) shows that all the compounds have a crystalline structure, without evidence for formation of isomorphous compounds and the crystallinity of these compounds follows the order $\mathrm{Nd}>\mathrm{Pr}>\mathrm{La} \sim \mathrm{Ce}>\mathrm{Sm} \sim \mathrm{Eu}>\mathrm{Gd}$. The difference in the crystallinity of the compounds must be due to precipitation conditions, which were not controlled.

\section{Infrared spectroscopy}

The attenuated total reflectance infrared spectroscopic data on isonicotinate (sodium salt) and its compounds with the metal ions considered in this work are shown in Fig. 2. The investigation was focused mainly in the $1700-1400 \mathrm{~cm}^{-1}$ range, because this region is potentially most informative in attempting to assign coordination sites, and the frequencies of interest are shown in Table 2.

In isonicotinate (sodium salt), medium-intensity band at $1542 \mathrm{~cm}^{-1}$ and a strong band at $1410 \mathrm{~cm}^{-1}$ are attributed to the antisymmetric $\left(v_{\mathrm{as}} \mathrm{CO}_{2}{ }^{-}\right)$and symmetric $\left(v_{\mathrm{sym}} \mathrm{CO}_{2}{ }^{-}\right)$ stretching frequencies of carboxylate groups, respectively $[16,17]$. For the synthesized compounds, these frequencies are located between 1547-1539 and 1414-1404 $\mathrm{cm}^{-1}$, respectively. Analysis of the frequencies of the $v_{\mathrm{as}} \mathrm{CO}_{2}{ }^{-}$ and $v_{\mathrm{sym}} \mathrm{CO}_{2}{ }^{-}$indicates that the coordination is carried out through the carboxylate [16] and the infrared spectra data suggest that the bonding of the carboxylate group to metal is bridging bidentate [18].

\section{Thermal analysis}

\section{TG-DSC in dry air atmosphere}

The simultaneous TG-DSC curves of the compounds in dry air atmosphere are shown in Fig. 3. These curves show mass losses in two or three steps and endothermic peaks attributed to dehydration, thermal decomposition, or physical phenomenon and exothermic peaks attributed to oxidation of the organic matter and/or of the gaseous products evolved during the thermal decomposition.

The thermal stability of the hydrated compounds (I) or anhydrous ones (II) and the final temperature of thermal decomposition (III), as well as the dehydration temperature range (IV) as shown by the TG-DSC curves, depend on the nature of the metal ion, and they follow the order:

(I) $\mathrm{Sm}>\mathrm{La}=\mathrm{Ce}=\mathrm{Pr}=\mathrm{Nd}=\mathrm{Eu}>\mathrm{Gd}$

(II) $\mathrm{La}>\mathrm{Pr}>\mathrm{Eu}>\mathrm{Nd}>\mathrm{Sm}>\mathrm{Gd}>\mathrm{Ce}$ 
Fig. 1 X-ray powder diffractograms: (a) $\mathrm{LaL}_{3} \cdot 2 \mathrm{H}_{2} \mathrm{O}$;

(b) $\mathrm{CeL}_{3} \cdot 2 \mathrm{H}_{2} ;$ (c) $\mathrm{PrL}_{3} \cdot 2 \mathrm{H}_{2} \mathrm{O}$;

(d) $\mathrm{NdL}_{3} \cdot 2 \mathrm{H}_{2} \mathrm{O}$

(e) $\mathrm{SmL}_{3} \cdot 2 \mathrm{H}_{2} \mathrm{O} ;(f) \mathrm{EuL}_{3} \cdot 2 \mathrm{H}_{2} \mathrm{O}$;

(g) $\mathrm{GdL}_{3} \cdot 2 \mathrm{H}_{2} \mathrm{O}$

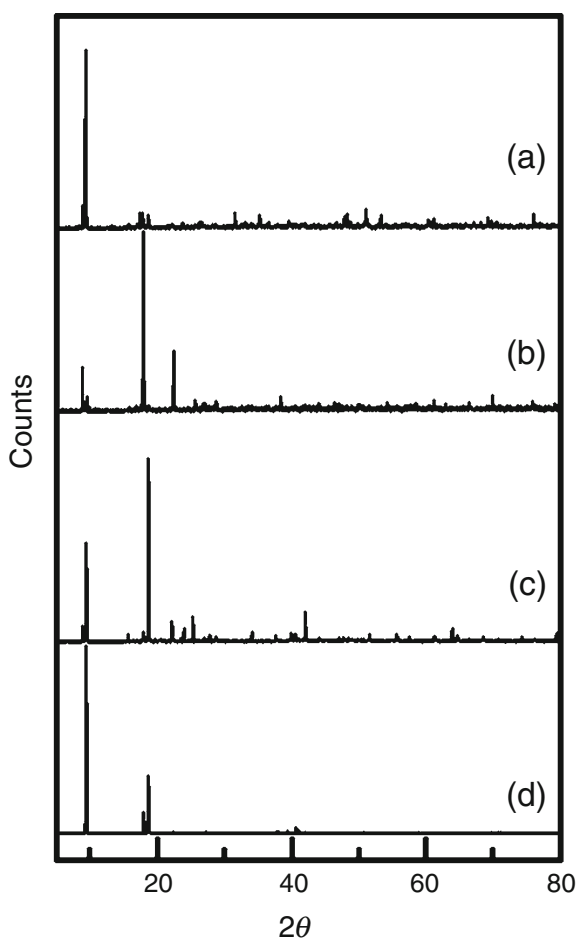

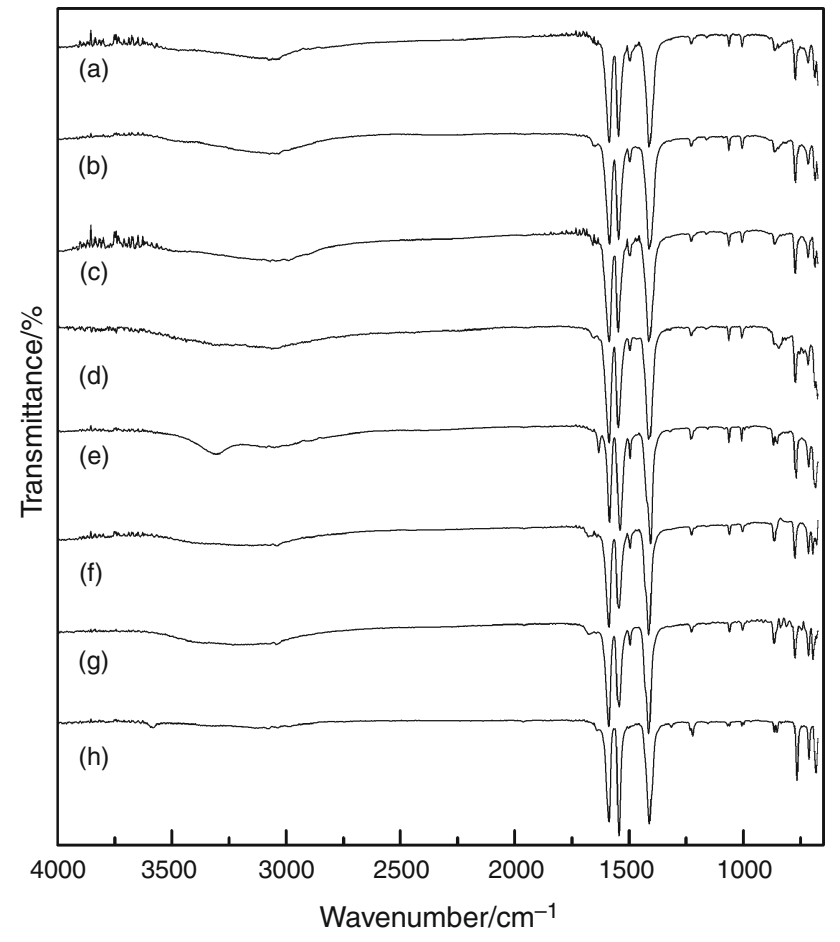

Fig. 2 FTIR spectra of: (a) $\mathrm{LaL}_{3} \cdot 2 \mathrm{H}_{2} \mathrm{O}$; (b) $\mathrm{CeL}_{3} \cdot 2 \mathrm{H}_{2}$; (c) $\mathrm{PrL}_{3} \cdot 2 \mathrm{H}_{2} \mathrm{O}$; (d) $\mathrm{NdL}_{3} \cdot 2 \mathrm{H}_{2} \mathrm{O}$; (e) $\mathrm{SmL}_{3} \cdot 2 \mathrm{H}_{2} \mathrm{O}$; ff $\mathrm{EuL}_{3} \cdot 2 \mathrm{H}_{2} \mathrm{O}$; $(g) \mathrm{GdL}_{3} \cdot 2 \mathrm{H}_{2} \mathrm{O}$; (h) $\mathrm{NaL}$

(III) $\mathrm{Pr}>\mathrm{Sm}>\mathrm{La}>\mathrm{Nd}=\mathrm{Eu}=\mathrm{Gd}>\mathrm{Ce}$

(IV) $\mathrm{Sm}>\mathrm{Nd}>\mathrm{Pr}>\mathrm{Ce}>\mathrm{La}>\mathrm{Eu}=\mathrm{Gd}$
Table 2 Experimental spectroscopic data for sodium isonicotinate and its compounds with light trivalent lanthanides ions, except promethium

\begin{tabular}{llll}
\hline Compounds & \multicolumn{3}{l}{ FTIR } \\
\cline { 2 - 4 } & $v_{\text {as }}^{\left(\mathrm{CO}_{2}^{-}\right)} / \mathrm{cm}^{-1}$ & $v_{\text {sym }}^{\left(\mathrm{CO}_{2}^{-}\right)} / \mathrm{cm}^{-1}$ & $\Delta v / \mathrm{cm}^{-1}$ \\
\hline $\mathrm{NaL}$ & 1542 & 1410 & 132 \\
$\mathrm{LaL}_{3} \cdot 2 \mathrm{H}_{2} \mathrm{O}$ & 1547 & 1412 & 135 \\
$\mathrm{CeL}_{3} \cdot 2 \mathrm{H}_{2} \mathrm{O}$ & 1545 & 1411 & 134 \\
$\mathrm{PrL}_{3} \cdot 2 \mathrm{H}_{2} \mathrm{O}$ & 1546 & 1413 & 133 \\
$\mathrm{NdL}_{3} \cdot 2 \mathrm{H}_{2} \mathrm{O}$ & 1547 & 1414 & 133 \\
$\mathrm{SmL}_{3} \cdot 2 \mathrm{H}_{2} \mathrm{O}$ & 1539 & 1404 & 135 \\
$\mathrm{EuL}_{3} \cdot 2 \mathrm{H}_{2} \mathrm{O}$ & 1543 & 1414 & 129 \\
$\mathrm{GdL}_{3} \cdot 2 \mathrm{H}_{2} \mathrm{O}$ & 1543 & 1414 & 129 \\
\hline
\end{tabular}

$L$ isonicotinate, $v_{\mathrm{as}}^{\left(\mathrm{COO}^{-}\right)}$carboxylate asymmetric stretching frequency, $v_{\mathrm{sym}}^{\left(\mathrm{COO}^{-}\right)}$carboxylate symmetric stretching frequency, $\Delta v$ difference between $v_{\mathrm{as}}^{\left(\mathrm{COO}^{-}\right)}$and $v_{\mathrm{sym}}^{\left(\mathrm{COO}^{-}\right)}$frequencies

These curves also show that all the compounds were obtained as dihydrated and the dehydration occurs in a single step. Three patterns of thermal behavior are observed for the compounds. Firstly, a close similarity is noted concerning the TG-DSC profiles of lanthanum and neodymium to gadolinium Fig. 3a, d-g. On the other hand, cerium and praseodymium, Fig. 3b, c, display a TG-DSC profile characteristic for each compound. Thus, the features of each compound are discussed based on their similar thermal profiles. 
Fig. 3 TG-DSC curves in dynamic dry air atmosphere.

(a) $\mathrm{LaL}_{3} \cdot 2 \mathrm{H}_{2} \mathrm{O}(10.0172 \mathrm{mg})$;

(b) $\mathrm{CeL}_{3} \cdot 2 \mathrm{H}_{2} \mathrm{O}(10.0184 \mathrm{mg})$;

(c) $\mathrm{PrL}_{3} \cdot 2 \mathrm{H}_{2} \mathrm{O}(10.0822 \mathrm{mg})$;

(d) $\mathrm{NdL}_{3} \cdot 2 \mathrm{H}_{2} \mathrm{O}(9.9793 \mathrm{mg})$;

(e) $\mathrm{SmL}_{3} \cdot 2 \mathrm{H}_{2} \mathrm{O}(9.9682 \mathrm{mg})$;

(f) $\mathrm{EuL}_{3} \cdot 2 \mathrm{H}_{2} \mathrm{O}(10.0662 \mathrm{mg})$;

(g) $\mathrm{GdL}_{3} \cdot 2 \mathrm{H}_{2} \mathrm{O}(10.0952 \mathrm{mg})$

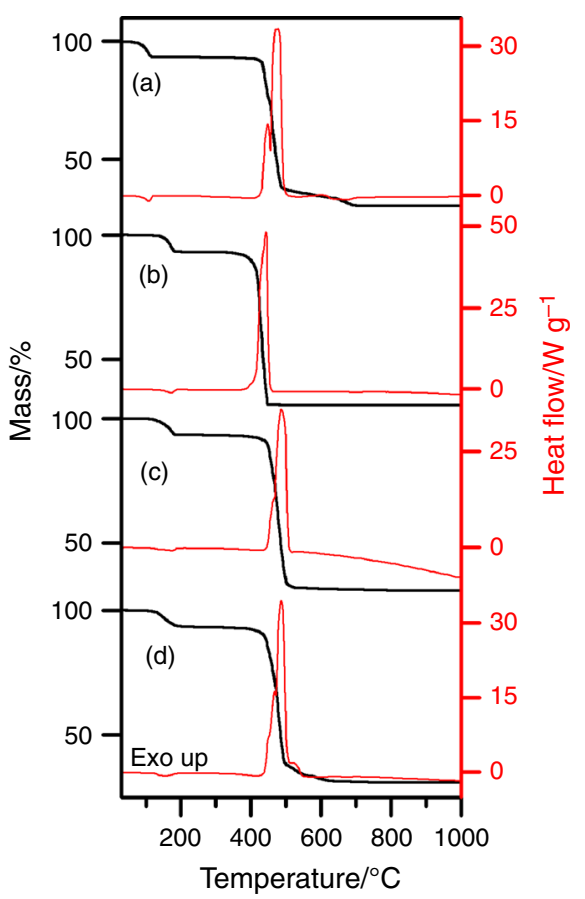

\section{Cerium compound}

The TG-DSC curves are shown in Fig. 3b. The first mass loss between 110 and $180{ }^{\circ} \mathrm{C}$, corresponding to an endothermic peak at $170{ }^{\circ} \mathrm{C}$, is attributed to dehydration, with loss of $2 \mathrm{H}_{2} \mathrm{O}$ molecules (Calcd. $=6.64 \%$, $\mathrm{TG}=6.77 \%$ ). The anhydrous compound is stable up to $340{ }^{\circ} \mathrm{C}$, and above this temperature the thermal decomposition occurs in a single step and through a fast process up to $450{ }^{\circ} \mathrm{C}$. The broad and sharp exothermic peak at $440{ }^{\circ} \mathrm{C}$, corresponding to this mass loss is attributed to oxidation reaction of $\mathrm{Ce}$ (III) to $\mathrm{Ce}(\mathrm{IV})$, together with the oxidation of the organic matter and/or the gaseous products evolved during the thermal decomposition. The smaller thermal stability of the cerium compound undoubtedly is due to oxidation reaction of $\mathrm{Ce}$ (III) and had already been observed for other cerium compound [19]. The total mass loss up to $450{ }^{\circ} \mathrm{C}$ is in agreement with the formation of cerium(IV) oxide, $\mathrm{CeO}_{2}$, as final residue (Calcd. $=$ $68.27 \%, \mathrm{TG}=68.41 \%)$.

\section{Praseodymium compound}

The TG-DSC curves are shown in Fig. 3c. The first mass loss between 110 and $190{ }^{\circ} \mathrm{C}$, corresponding to a small and broad endothermic event $\left(120-190{ }^{\circ} \mathrm{C}\right)$, is attributed to dehydration, with loss of $2 \mathrm{H}_{2} \mathrm{O}$ molecules (Calcd. $=6.63 \%$, TG $=6.69 \%)$. The anhydrous compound is stable up to $400{ }^{\circ} \mathrm{C}$, and above this temperature the thermal decomposition occurs in two steps between
400-510 and $510-720{ }^{\circ} \mathrm{C}$, with losses of 61.14 and $1.06 \%$, respectively. The first step that occurs through a fast process, corresponding to a large and sharp exothermic peak at $490{ }^{\circ} \mathrm{C}$ with shoulder at $470{ }^{\circ} \mathrm{C}$ is attributed to oxidation of organic matter and/or gaseous products evolved during the thermal decomposition together with the oxidative reaction of $\operatorname{Pr}(\mathrm{III})$ to $\operatorname{Pr}_{6} \mathrm{O}_{11}$, with formation of small amount of carbonaceous residue.

The last step is attributed to oxidation of carbonaceous residue. No thermal event is observed in this step because the heat involved is not sufficient to produce a thermal event, undoubtedly due to the small amount of residue and the mass loss that occurs slowly. The total mass loss up to $720{ }^{\circ} \mathrm{C}$ is in agreement with the formation of praseodymium oxide, $\operatorname{Pr}_{6} \mathrm{O}_{11}$, as final residue (Calcd. $=62.03 \%$; $\mathrm{TG}=62.20 \%$ ).

\section{Lanthanum and neodymium to gadolinium compounds}

The TG-DSC curves are shown in Fig. 3a, d-g. For all the compounds the first mass loss between $110-175^{\circ} \mathrm{C}(\mathrm{La})$, $110-200{ }^{\circ} \mathrm{C}(\mathrm{Nd}), 125-230{ }^{\circ} \mathrm{C}(\mathrm{Sm}), 110-160{ }^{\circ} \mathrm{C}(\mathrm{Eu})$, and $105-155^{\circ} \mathrm{C}(\mathrm{Gd})$, corresponding to an endothermic peak at $170{ }^{\circ} \mathrm{C}(\mathrm{La}), 145{ }^{\circ} \mathrm{C}(\mathrm{Eu}), 140{ }^{\circ} \mathrm{C}(\mathrm{Gd})$, and a small and broad endothermic event around $150{ }^{\circ} \mathrm{C}(\mathrm{Nd})$ and $210{ }^{\circ} \mathrm{C}(\mathrm{Sm})$ is attributed to dehydration with loss of $2 \mathrm{H}_{2} \mathrm{O}$ (Calcd., TG: $\mathrm{La}=6.66 \%, 6.70 \%$; $\mathrm{Nd}=6.59 \%, 6.71 \%$; $\mathrm{Sm}=6.52 \%, \quad 6.73 \% ; \quad \mathrm{Eu}=6.50 \%, \quad 6.65 \% ; \quad \mathrm{Gd}=$ $6.44 \%, 6.54 \%)$. 
Fig. 4 TG-DSC curves in $\mathrm{N}_{2}$ atmosphere. (a) $\mathrm{LaL}_{3} \cdot 2 \mathrm{H}_{2} \mathrm{O}$ (10.0527 mg); (b) $\mathrm{CeL}_{3} \cdot 2 \mathrm{H}_{2} \mathrm{O}$ (10.0066 mg); (c) $\mathrm{PrL}_{3} \cdot 2 \mathrm{H}_{2} \mathrm{O}$ (9.9927 mg); (d) $\mathrm{NdL}_{3} \cdot 2 \mathrm{H}_{2} \mathrm{O}$ $(9.9977 \mathrm{mg}) ;\left(\right.$ e) $\mathrm{SmL}_{3} \cdot 2 \mathrm{H}_{2} \mathrm{O}$ $(10.0018 \mathrm{mg}) ;(f) \mathrm{EuL}_{3} \cdot 2 \mathrm{H}_{2} \mathrm{O}$ $(10.0170 \mathrm{mg}) ;(g) \mathrm{GdL}_{3} \cdot 2 \mathrm{H}_{2} \mathrm{O}$ (10.0213 mg)

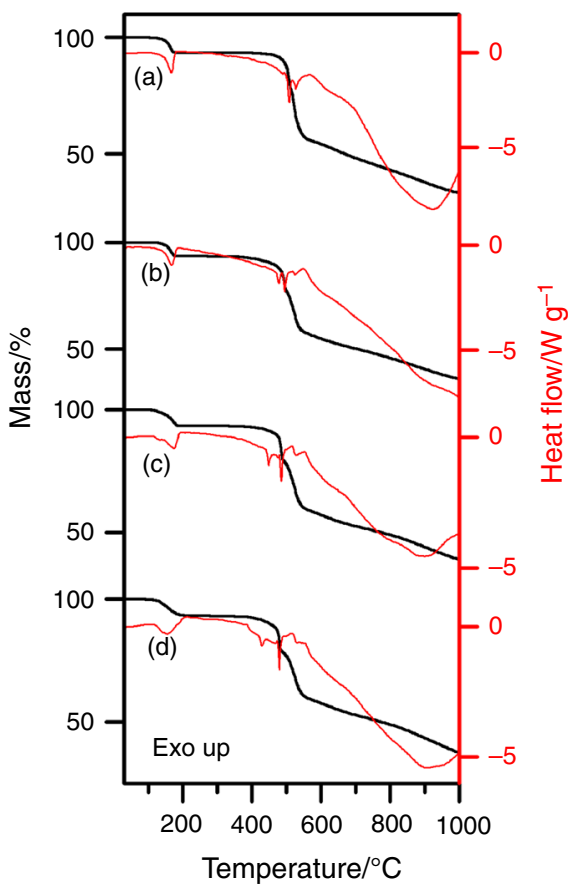

The anhydrous compounds are stable up to $430{ }^{\circ} \mathrm{C}(\mathrm{La})$, $370{ }^{\circ} \mathrm{C}(\mathrm{Nd}), 360{ }^{\circ} \mathrm{C}(\mathrm{Sm}), 375{ }^{\circ} \mathrm{C}(\mathrm{Eu})$, and $345^{\circ} \mathrm{C}(\mathrm{Gd})$, and above these temperatures the thermal decomposition occurs in two consecutive steps. For lanthanum and neodymium compounds, the first step occurs between $430-515{ }^{\circ} \mathrm{C}$ (La) and $370-510{ }^{\circ} \mathrm{C}(\mathrm{Nd})$ although the DSC curves suggest two overlapping steps, the mass loss occurs through a fast process with loss of 55.63 and $55.45 \%$ respectively. For samarium, europium, and gadolinium compounds the first step between $360-520{ }^{\circ} \mathrm{C}(\mathrm{Sm}), \quad 375-490{ }^{\circ} \mathrm{C}(\mathrm{Eu})$, and $345-495{ }^{\circ} \mathrm{C}(\mathrm{Gd})$, and the mass loss also occurs through a fast process with loss of 55.18, 56.49, and $54.46 \%$, respectively.

The exothermic peaks at 470 and $495{ }^{\circ} \mathrm{C}(\mathrm{La}), 470$ and $490{ }^{\circ} \mathrm{C}(\mathrm{Nd}), 505{ }^{\circ} \mathrm{C}(\mathrm{Sm}), 470{ }^{\circ} \mathrm{C}(\mathrm{Eu})$, and $485{ }^{\circ} \mathrm{C}(\mathrm{Gd})$ are attributed to oxidation of the organic matter and/or the gaseous products evolved during the thermal decomposition, with the formation of carbonaceous residue and a derivative of carbonate, which were confirmed by tests with hydrochloric acid solution on sample heated up to the temperature indicated by TG-DSC curves.

The last step that occurs through a slow process, between $510-695{ }^{\circ} \mathrm{C}(\mathrm{La}), 510-690{ }^{\circ} \mathrm{C}(\mathrm{Nd}), 520-715{ }^{\circ} \mathrm{C}$ (Sm), 490-690 ${ }^{\circ} \mathrm{C}(\mathrm{Eu})$, and $495-690^{\circ} \mathrm{C}(\mathrm{Gd})$ with loss of $7.45,6.87,6.54,5.44$, and $6.74 \%$, corresponding to an exothermic event at $570,610,530,555,540$, and $570{ }^{\circ} \mathrm{C}$, respectively, followed by an endothermic between $630-690{ }^{\circ} \mathrm{C}(\mathrm{La}), 550-610{ }^{\circ} \mathrm{C}(\mathrm{Nd}), 590-620{ }^{\circ} \mathrm{C}(\mathrm{Sm})$, $555-590{ }^{\circ} \mathrm{C}(\mathrm{Eu})$, and $590-620{ }^{\circ} \mathrm{C}(\mathrm{Gd})$ attributed to oxidation of the carbonaceous residue and the thermal decomposition of derivative of carbonate.
Fig. 5 DSC curves in dry air $(a-g)$ and $\mathrm{N}_{2}\left(a^{*}-g *\right)$ atmospheres. (Sample mass: air/ $\mathrm{N}_{2}$ ): (a) $\mathrm{LaL}_{3} \cdot 2 \mathrm{H}_{2} \mathrm{O}(2.063 /$ $2.054 \mathrm{mg}$ ); (b) $\mathrm{CeL}_{3} \cdot 2 \mathrm{H}_{2} \mathrm{O}$ (2.089/2.048 mg);

(c) $\mathrm{PrL}_{3} \cdot 2 \mathrm{H}_{2} \mathrm{O}(2.049 /$ $2.050 \mathrm{mg}) ;($ d $) \mathrm{NdL}_{3} \cdot 2 \mathrm{H}_{2} \mathrm{O}$ (2.141/2.155 mg); (e) $\mathrm{SmL}_{3} \cdot 2 \mathrm{H}_{2} \mathrm{O}(2.024 /$ $2.041 \mathrm{mg}) ;(f) \mathrm{EuL}_{3} \cdot 2 \mathrm{H}_{2} \mathrm{O}$ (2.141/2.180 mg); (g) $\mathrm{GdL}_{3} \cdot 2 \mathrm{H}_{2} \mathrm{O}(2.148 /$ $2.175 \mathrm{mg}$ )
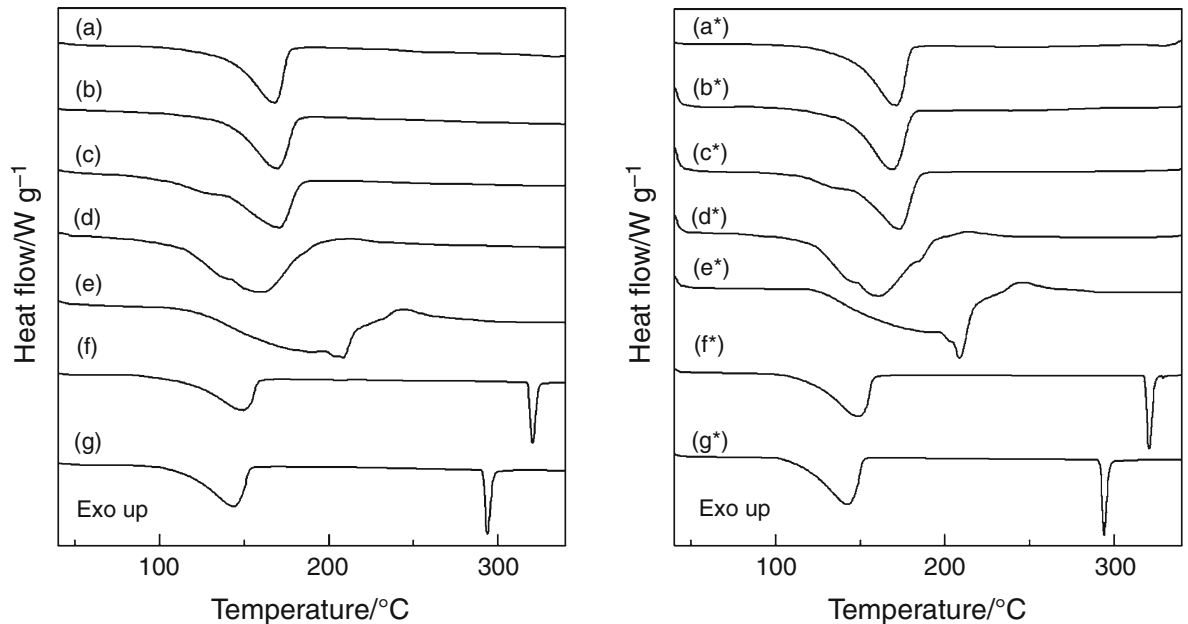
The total mass loss of these compounds up to the minimum oxide level temperatures are in agreement with the formation of the respective oxides, $\mathrm{Ln}_{2} \mathrm{O}_{3}(\mathrm{Ln}=\mathrm{La}, \mathrm{Nd}$, $\mathrm{Sm}, \mathrm{Eu}$ and $\mathrm{Gd}$ ) (Calcd., TG: $\mathrm{La}=63,24 \%, 63,08 \%$; $\mathrm{Nd}=62.63 \%, \quad 62,32 \% ; \quad \mathrm{Sm}=61.94 \%, \quad 61.72 \%$; $\mathrm{Eu}=61.75 \%, 61.93 \% ; \mathrm{Gd}=61.17 \%, 61.21 \%)$.

\section{$T G-D S C$ in $\mathrm{N}_{2}$ atmosphere}

The TG-DSC curves in dry nitrogen atmosphere are shown in Fig. 4. These curves show mass losses in three (Eu) or four ( $\mathrm{La}$ to $\mathrm{Sm}$ and $\mathrm{Gd}$ ) steps and endothermic peaks attributed to dehydration, pyrolysis and physical phenomenon or without thermal event.

The thermal stability of the hydrated compounds (I) or anhydrous ones (II) and the final temperature of thermal decomposition (III) as shown by the TG-DSC curves are not the same from that observed in dry air atmosphere, and they follow the order:

(I) $\mathrm{Sm}>\mathrm{La}>\mathrm{Ce}=\mathrm{Eu}>\mathrm{Gd}>\mathrm{Pr}=\mathrm{Nd}$

(II) $\mathrm{La}>\mathrm{Pr}>\mathrm{Gd}>\mathrm{Eu}>\mathrm{Nd}=\mathrm{Sm}>\mathrm{Ce}$

For all the compounds, these curves also show that the mass loss is still being observed up to $1000{ }^{\circ} \mathrm{C}$, and except for europium, a great similarity is observed concerning the TG-DSC profiles of these compounds, Fig. 4a-e, g. On that account, the features of each compound are also discussed based on these similar profiles.

\section{Europium compound}

The TG-DSC curves are shown in Fig. 4f. The first mass loss between 110 and $160{ }^{\circ} \mathrm{C}$, corresponding to an endothermic

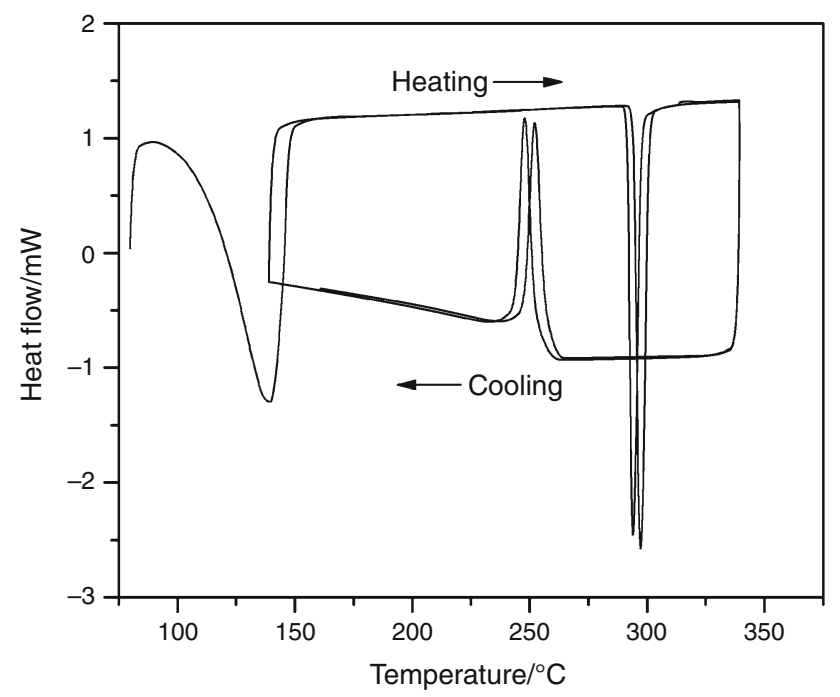

Fig. 6 DSC cycle (heating/cooling/heating/cooling) of gadolinium compound, showing the exothermic peak on cooling attributed to the reversible phase transition peak at $145{ }^{\circ} \mathrm{C}$, is attributed to dehydration, with loss of 2 $\mathrm{H}_{2} \mathrm{O}$ molecules (Calcd. $=6.50 \%, \mathrm{TG}=6.59 \%$ ).

The anhydrous compounds are stable up to $380{ }^{\circ} \mathrm{C}$, and above this temperature the thermal decomposition occurs in two consecutive steps between $380-520$ and 520$>1000{ }^{\circ} \mathrm{C}$, with losses of 36,91 and $>22,76 \%$, corresponding to endothermic peaks at 475 and $915{ }^{\circ} \mathrm{C}$ attributed to thermal decomposition of the compounds and pyrolysis of the carbonaceous residue.

\section{Lanthanum to samarium and gadolinium compounds}

The TG-DSC curves are shown in Fig. 4a-e, g. For all the compounds, the first mass loss between $120-180{ }^{\circ} \mathrm{C}(\mathrm{La})$, $110-180{ }^{\circ} \mathrm{C}(\mathrm{Ce}), 100-190{ }^{\circ} \mathrm{C}(\mathrm{Pr}), 100-210{ }^{\circ} \mathrm{C}(\mathrm{Nd})$, $130-210{ }^{\circ} \mathrm{C}(\mathrm{Sm})$, and $105-150{ }^{\circ} \mathrm{C}(\mathrm{Gd})$, corresponding to an endothermic peak at $170^{\circ} \mathrm{C}(\mathrm{La}, \mathrm{Ce}), 175^{\circ} \mathrm{C}(\mathrm{Pr})$, $155{ }^{\circ} \mathrm{C}(\mathrm{Nd}), 140{ }^{\circ} \mathrm{C}(\mathrm{Gd})$ and an endotherm between $130-220^{\circ} \mathrm{C}(\mathrm{Sm})$, is attributed to dehydration with loss of $2 \mathrm{H}_{2} \mathrm{O}$ molecules ( $\mathrm{La}$ to $\mathrm{Sm}, \mathrm{Gd}$; Calcd. $=6.66,6.64,6.63$, $6.59,6.52,6.44 \% ; \mathrm{TG}=6.65,6.61,6.57,6.85,6.66,6.59$, $6.51 \%$, respectively).

The anhydrous compounds ( $\mathrm{La}$ to $\mathrm{Sm}, \mathrm{Gd}$ ) are stable up to $420,315,400,370,370,390{ }^{\circ} \mathrm{C}$, and above these temperatures the thermal decomposition occurs in three consecutive steps between $420-510,510-560$, and $560->1000{ }^{\circ} \mathrm{C}(\mathrm{La})$; $315-500,500-550$, and $550->1000{ }^{\circ} \mathrm{C}(\mathrm{Ce}) ; 400-490$, 490-555, and 555->1000 ${ }^{\circ} \mathrm{C}(\operatorname{Pr}) ; 370-485,485-560$, and $560->1000{ }^{\circ} \mathrm{C} \quad(\mathrm{Nd}) ; \quad 370-490, \quad 490-550$, and 550 $>1000{ }^{\circ} \mathrm{C}(\mathrm{Sm}) ; 390-500,500-545$, and $545->1000{ }^{\circ} \mathrm{C}$ (Gd), respectively. The first two steps that occur through fast processes with losses of 5.54 and $22.71 \%$ (La), 15.81 and $19.44 \%(\mathrm{Ce}), 13.51$ and $20.26 \%(\mathrm{Pr}), 14.21$ and $18.94 \%$ (Nd), 13.03 and $19.67 \%(\mathrm{Sm}), 15.85$ and $21.44 \%(\mathrm{Gd})$ corresponding to endothermic peaks at 490,510 and $525{ }^{\circ} \mathrm{C}$ (La), 480, 495, and $595^{\circ} \mathrm{C}(\mathrm{Ce}), 450,480,485$, and $530{ }^{\circ} \mathrm{C}(\mathrm{Pr}), 430,465,480$, and $530{ }^{\circ} \mathrm{C}(\mathrm{Nd}), 480,495$, and $530{ }^{\circ} \mathrm{C}(\mathrm{Sm}), 495$ and $520{ }^{\circ} \mathrm{C}(\mathrm{Gd})$, attributed to the thermal decomposition and formation of carbonaceous residue.

The last mass loss that occurs slowly and is still being observed up to $1000{ }^{\circ} \mathrm{C}$ is attributed to the pyrolysis of the carbonaceous residue.

In both atmospheres (air, N2), the endothermic peak at $370{ }^{\circ} \mathrm{C}(\mathrm{Sm}), 320{ }^{\circ} \mathrm{C}(\mathrm{Eu})$, and $275^{\circ} \mathrm{C}(\mathrm{Gd})$ without mass loss in TG curve is attributed to irreversible phase transition.

DSC

The DSC curves in nitrogen and air atmospheres, measured up to $350{ }^{\circ} \mathrm{C}$, are shown in Fig. $5 \mathrm{a}-\mathrm{g}$ and Fig. $5 \mathrm{a}^{*}-\mathrm{g}^{*}$, respectively. In both atmospheres (air, $\mathrm{N}_{2}$ ) these curves show endothermic peaks at 171 and $168{ }^{\circ} \mathrm{C}(\mathrm{La}), 170{ }^{\circ} \mathrm{C}(\mathrm{Ce}) 173$ 
Fig. 7 DSC-photovisual micrographs of $\mathrm{GdL}_{3} \cdot 2 \mathrm{H}_{2} \mathrm{O}$ showing the crystal change on dehydration (upper left/right) and phase transition (bottom left/right)
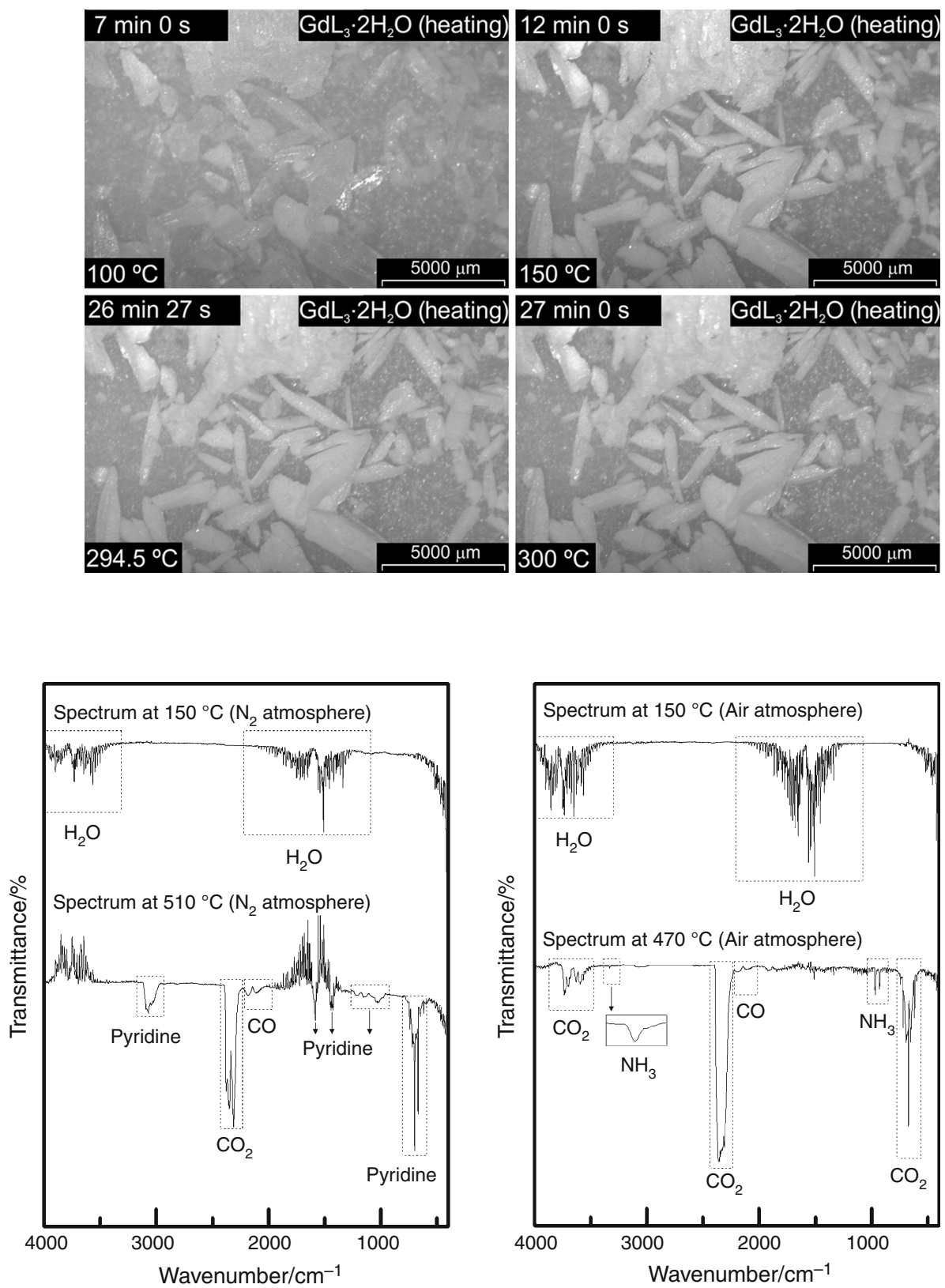

Fig. 8 FTIR spectra of gases evolved during thermal decomposition of Lanthanum compound $\left(\mathrm{LaL}_{3} \cdot 2 \mathrm{H}_{2} \mathrm{O}\right)$, in air and $\mathrm{N}_{2}$ atmospheres and $171{ }^{\circ} \mathrm{C}(\mathrm{Pr}), 161$ and $160{ }^{\circ} \mathrm{C}(\mathrm{Nd}), 209{ }^{\circ} \mathrm{C}(\mathrm{Sm}), 250{ }^{\circ} \mathrm{C}$ (Eu), 143 and $144{ }^{\circ} \mathrm{C}(\mathrm{Gd})$ attributed to dehydration, and at $321(\mathrm{Eu})$ and $294{ }^{\circ} \mathrm{C}(\mathrm{Gd})$ due to reversible phase transition. The dehydration enthalpies calculated for these compounds were 103.6 and $110.6(\mathrm{La}), 110.6$ and $106.3(\mathrm{Ce}), 121.0$ and $119.3(\mathrm{Pr}), 129.8$ and $139.8(\mathrm{Nd}), 161.9$ and 177.7 (Sm), 108.9 and $106.1(\mathrm{Sm}), 109.5$ and $108.3(\mathrm{Gd}) \mathrm{kJ} \mathrm{mol}^{-1}$, in air and $\mathrm{N}_{2}$ atmospheres, respectively.

For europium and gadolinium compounds, the reversible phase transition enthalpies were 26.4 and $27.1(\mathrm{Eu}), 26.0$ and $26.0(\mathrm{Gd}) \mathrm{kJ} \mathrm{mol}^{-1}$, in air and $\mathrm{N}_{2}$ atmospheres, respectively. The reversibility of phase transition was confirmed by DSC heating/cooling cycles for the compounds, as indicated by the exothermic peaks observed around $250{ }^{\circ} \mathrm{C}$ in Fig. 6. Only the gadolinium compound DSC curves are shown as representative.

The DSC-photovisual micrograph shows visible changes in the crystal aspect, while the gadolinium compound is heated, as illustrated in Fig. 7. The first thermal event attributed to dehydration $\left(\sim 140{ }^{\circ} \mathrm{C}\right)$ causes a slight change in the crystal opacity, passing from slightly translucent to an opaque white color, Fig. 7 (upper left/right). At about $295^{\circ} \mathrm{C}$, the compound pass through the phase transition and it is possible to observe the contraction of the crystals, possibly due to a rearrangement of the crystal lattice, as illustrated in Fig. 7 (bottom left/right). On cooling it is also 
possible to observe the reverse phenomenon at around $250{ }^{\circ} \mathrm{C}$, but this time only a slight change on the position of the crystals is visible. For more details see the video in supplementary material.

\section{Evolved gas analysis}

The gaseous products evolved during the thermal decomposition of light trivalent lanthanide isonicotinates in both atmospheres were monitored by FTIR, and in all the compounds were detected ammonia, carbon monoxide and carbon dioxide (air) or pyridine, carbon monoxide and carbon dioxide $\left(\mathrm{N}_{2}\right)$. The IR spectra of gaseous products detected during thermal decomposition of Lanthanum compound, as representative of all the synthesized compounds in this work are shown in Fig. 8.

\section{Conclusions}

From TG, complexometry, and elemental analysis data, a general formula could be established for the synthesized compounds.

The infrared spectroscopic data suggest that the isonicotinate act as a bridging bidentate ligand toward the light trivalent lanthanides.

The monitoring of evolved gases (EGA) shows that during the thermal decomposition the compounds occurs the release of ammonia, $\mathrm{CO}$ and $\mathrm{CO}_{2}$ (air) and pyridine, $\mathrm{CO}$ and $\mathrm{CO}_{2}\left(\mathrm{~N}_{2}\right)$.

From DSC and DSC-photovisual analysis, it was possible to measure the enthalpies of dehydration and evaluate the reversibility of the phase transitions for gadolinium and europium compounds.

The TG-DSC and DSC curves also provided previously unreported information about the thermal stability and thermal decomposition in dynamic dry and nitrogen atmospheres.

Acknowledgements The authors thank FAPESP (Proc. 2013/090227), $\mathrm{CNPq}$, and CAPES foundations (Brazil) for financial support.

\section{References}

1. De Sá GF, Malta OL, de Mello Donegá C, Simas AM, Longo RL, Santa-Cruz PA, et al. Spectroscopic properties and design of highly luminescent lanthanide coordination complexes. Coord Chem Rev. 2000. http://www.sciencedirect.com/science/article/ pii/S0010854599000545.

2. Van Loenhout-Rooyackers JH, Veen J. Treatment of pulmonary tuberculosis. Neth J Med. 1998;53:7-14. http://www.sciencedir ect.com/science/article/pii/S0300297798000679.
3. Lin CZJ, Chui SSY, Lo SMF, Shek FLY, Wu M, Suwinska K, et al. Physical stability vs. chemical lability in microporous metal coordination polymers: a comparison of $[\mathrm{Cu}(\mathrm{OH})(\mathrm{INA})] \mathrm{n}$ and $[\mathrm{Cu}(\mathrm{INA}) 2] \mathrm{n}$ : INA $=1,4-\left(\mathrm{NC}_{5} \mathrm{H}_{4} \mathrm{CO}_{2}\right)$. Chem Commun (Camb). 2002;1:1642-3.

4. Duan LM, Lin CK, Wang H, Liu XM, Lin J. Syntheses, structures and luminescence properties of five lanthanide-isonicotinate coordination polymers. Inorg Chim Acta. 2010;363:1507-12. doi:10.1016/j.ica.2010.01.018.

5. Almeida Paz FA, Klinowski J. Hydrothermal synthesis of a novel thermally stable three-dimensional ytterbium-organic framework. Chem Commun. 2003. doi:10.1039/B302140H.

6. Chen W, Fukuzumi S. Ligand-dependent ultrasonic-assistant selfassemblies and photophysical properties of lanthanide nicotinic/ isonicotinic complexes. Inorg Chem. 2009;48:3800-7.

7. Jia G, Law GL, Wong KL, Tanner PA, Wong WT. Synthesis, crystal structures, and luminescence of organic-lanthanide complexes with nicotinate and isonicotinate ligands. Inorg Chem. 2008;47:9431-8.

8. Huang L, Han L, Zhu D, Chen L, Xu Y. Hydrothermal synthesis, crystal structure and luminescence of two new 2D coordination polymers $\left[\mathrm{Ln}(\mathrm{IN})\left(\mathrm{CO}_{3}\right)\left(\mathrm{H}_{2} \mathrm{O}\right)\right](\mathrm{LnLa}, \mathrm{Eu})$ constructed by interesting flat lanthanide carbonate layers. Inorg Chem Commun. 2012;21:80-3. doi:10.1016/j.inoche.2012.04.018.

9. Naumova MI, Manicheva EA, Geraski OA, Fedin VP. Synthesis and crystal structures of new lanthanide isonicotinates: coordination polymers and molecular complexes. Russ Chem Bull. 2009;58:1858-65.

10. Hilder M, Lezhnina M, Junk PC, Kynast UH. Spectroscopic properties of lanthanoid benzene carboxylates in the solid state: Part 3. N-heteroaromatic benzoates and 2-furanates. Polyhedron. 2013;52:804-9. doi:10.1016/j.poly.2012.07.047.

11. Yan B, Zhou B. Photophysical properties of dysprosium complexes with aromatic carboxylic acids by molecular spectroscopy. J Photochem Photobiol A Chem. 2005;171:181-6.

12. Ma L, Evans OR, Foxman BM, Lin W. Luminescent lanthanide coordination polymers. Inorg Chem. 1999;38:5837-40.

13. Colman TAD, Gomes DJC, Caires FJ, Filho OT, da Silva RDC, Ionashiro M. Synthesis, thermal and spectroscopic study of light lanthanide nicotinate, in the solid state. Thermochim Acta. 2014;591:111-8. http://linkinghub.elsevier.com/retrieve/pii/ S0040603114002743.

14. Ionashiro M, Graner CAF, Netto JZ. Titulação complexométrica de lantanídeos e ítrio. Eclet Quim. 1983;8:29-32.

15. Flaschka HA. EDTA titrations. Oxford: Pergamon Press; 1964.

16. Nakamoto K. Infrared and Raman Spectra of Inorganic and Coordination Compounds, Part B. 5th ed. New York: Wiley; 1997.

17. Silverstein RM, Webster FX. Spectrometric identification of organic compounds. 6th ed. New York: Wiley; 1998.

18. Deacon GB, Phillips RJ. Relationships between the carbonoxygen stretching frequencies of carboxylato complexes and the type of carboxylate coordination. Coord Chem Rev. 1980;33: 227-50. http://www.sciencedirect.com/science/article/pii/S00108 54500804555 .

19. Lima LS, Caires FJ, Carvalho CT, Siqueira AB, Ionashiro M. Synthesis, characterization and thermal behaviour of solid-state compounds of light trivalent lanthanide succinates. Thermochim Acta. 2010;501:50-4. doi:10.1016/j.tca.2010.01.001. 